\title{
Effect of Entophytic Bacteria on the Rooting and Establishment of Cuttings of Hibiscus Rosasinensis
}

\author{
Anu Rajan, S. ${ }^{1}$ and Radhakrishna, D. ${ }^{2}$ \\ ${ }^{1,2}$ Department of Agricultural Microbiology, University of Agricultural Sciences, GKVK, Bangalore, India- \\ 560065 .
}

\begin{abstract}
Any plants that are propagated vegetatively are likely to have an enduring community of bacterial colonists that are transferred in successive progeny generations. The plant growth promoting effects attributed to endophytes are due to the direct production of phytohormones such as auxins, cytokinins etc or through the induction of phytohormone synthesis by the plant. Being a vegetatively propagated plant species, Hibiscus rosasinensis shoots are amenable for treatment with endophytic bacteria. The effect of endophytic bacteria on the rooting and establishment of cuttings of Hibiscus rosasinensis was studied here. Four endophytic isolates and the consortium of them screened for their plant hormone production was used for this study. The treatment of cuttings with the tomato isolate LEE19 (Klebsiella sp.) for 12 hours, showed $75 \%$ sprouting of cuttings and the highest shoot and root parameters compared to uninoculated cuttings. The rooting also increased to $100 \%$ in LEE19 treatment. The treatment of entophytic bacteria increased significantly the number of leaves/ cutting, the shoot length, root length and fresh weight of roots. So the pre-plant stem treatment of cuttings can be recommended as a strategy for substituting or supplementing the use of chemical plant growth hormones in vegetative propagation of cuttings.
\end{abstract}

Key Words: entophytic bacteria, Hibiscus rosasinensis, pre-plant stem treatment, vegetative propagation

\section{Introduction}

The art of propagation by cuttings is a very old technique popular in the field of horticulture. However, there are many species which are difficult to root. In recent years, many such difficult to root species are made to root easily by use of root inducing chemicals and modifying the surrounding environment. Endophytic bacteria are those that colonize the plant internal tissue showing no external sign of infection or negative effect on their host [1]. The plant growth effects attributed to endophytes include growth and developmental promotion through the direct production of phytohormones by it or through the induction of phytohormone synthesis by the plant. Any plants that are propagated vegetatively are likely to have an enduring community of bacterial colonists that are transferred in successive progeny generations. In vegetatively propagated plants like ornamental plants, horticultural crops etc endophytic bacteria can be directly delivered into the succulent plant system prior to the planting in the soil. Since the endophytic isolates obtained from the crop plants were found to produce the growth hormones IAA and GA in considerable amounts, the effect of these endophytic bacterial isolates on the rooting and establishment of cuttings of the ornamental plant, Hibiscus rosasinensis was studied. Being a vegetatively propagated plant species, Hibiscus rosasinensis shoots are amenable for treatment with endophytic bacteria.

\section{Materials and Methods}

\subsection{Isolation of endophytes from different crops}

Plant samples of rice, ragi, cowpea, soybean, groundnut, sunflower, chilli and tomato were collected from the Agricultural Farm, University of Agricultural Sciences, Bangalore. The endophytic bacteria were isolated from the shoots of the above plants by surface sterilization of shoot tissue with $70 \%$ ethanol followed by $3 \%$ sodium hypochlorite and plating on nutrient agar. Validation of sterility was done by plating the last wash water and checking for bacterial growth. Morphology and motility of cultured bacteria were examined by light microscopy. Standard morphological and biochemical characterization of the isolates with unique colony characters were carried out following standard procedures [2].

\subsection{Production of plant growth regulators by endophytic bacterial isolates}

\subsubsection{Extraction of plant growth regulators from culture filtrate [3]}

One $\mathrm{ml}$ of the standard inoculum $\left(10^{9}\right.$ cells $\left.\mathrm{ml}^{-1}\right)$ of endophytic isolates was added to $100 \mathrm{ml}$ nutrient broth and incubated at $30^{\circ} \mathrm{C}$ in a shaker. In order to avoid photo inactivation of the biologically active compounds, the flasks were wrapped with black paper during incubation. After 14 days of incubation, $25 \mathrm{ml}$ of the sample was withdrawn and the cells were spun at $5000 \mathrm{x} \mathrm{g}$ for $15 \mathrm{~min}$ in a centrifuge (Remi, India). The supernatant was acidified to $\mathrm{pH} 2.5$ using $5 \mathrm{~N}$ hydrochloric acid and partitioned with equal volumes of ethyl 
acetate for five times in a separating funnel. The ethyl acetate phase was dried at $32^{\circ} \mathrm{C}$ and the residue was redissolved in $2 \mathrm{ml}$ of distilled water.

\subsubsection{Spectrophotometric estimation of Gibberellins (GA) [4]}

To determine the amount of GA present in the supernatant of the culture, $2 \mathrm{ml}$ of ethyl acetate fraction was taken and $2 \mathrm{ml}$ of zinc acetate solution was added. After $2 \mathrm{~min}, 2 \mathrm{ml}$ of potassium ferrocyanide solution was added and the mixture was centrifuged at $10,000 \mathrm{rpm}$ for $10 \mathrm{~min}$. Five $\mathrm{ml}$ of supernatant was added to $5 \mathrm{ml}$ of 30 per cent hydrochloric acid and the mixture was incubated at $20^{\circ} \mathrm{C}$ for $75 \mathrm{~min}$. The blank was prepared with 5 per cent hydrochloric acid. The absorbance was measured at $254 \mathrm{~nm}$ in a spectrophotometer.

\subsubsection{Spectrophotometric estimation of IAA [5]}

A quantity of $0.5 \mathrm{ml}$ of the sample was taken in a test tube and $1.5 \mathrm{ml}$ of distilled water was added followed by $4 \mathrm{ml}$ of Salper's reagent and incubated in darkness for $1 \mathrm{~h}$ at $28^{\circ} \mathrm{C}$. The intensity of the pink colour developed was read in spectrophotometer at $535 \mathrm{~nm}$. By referring to a standard graph prepared with chemical grade of indole-3-acetic acid, the quantity of IAA in the sample was determined.

\subsection{Pre-plant bacterisation with endophytic isolates on the stem cuttings of the ornamental plant, Hibiscus rosasinensis.}

Endophytic isolates viz. ECE6, HAE7, LEE18, LEE19 and the consortium of the above four was used for this study. The experiment was designed in CRD with eight treatments and three replications with five cuttings each per replication.

\subsubsection{Treatment of cuttings with endophytic isolates}

The bacterial strains were grown separately and the four strains that are going to make up the consortium were added equally (v/v) and finally mixed at the time of inoculation. The cuttings were dipped in $200 \mathrm{ml}$ of the bacterial suspensions $\left(10^{6} \mathrm{cfu} / \mathrm{ml}\right)$ and incubated for 12 hours. Control was maintained by dipping the cuttings in distilled water.

\subsubsection{Treatment of cuttings with chemicals}

Effect of endophytic isolates on rooting was compared with the commercial formulation Quicroot as well as with the standard chemical IBA. Quicroot is a commercial formulation for rooting of cuttings from Ashwin Chemicals, Bangalore, which might be a combination of auxin (IBA) and other root promoting substances. The cut end of roots was dipped in this solution for 45 seconds before planting. $2500 \mathrm{ppm}$ of the pure grade chemical Indole Butyric Acid (IBA) solution was prepared and the cuttings were dipped to $5 \mathrm{~cm}$ deep in the solution for $30 \mathrm{sec}$.

\subsubsection{Planting and after care}

The treated cuttings were planted in the trays filled with rooting media, and placed inside the glass house. The trays were watered regularly. After 90 days of the planting into the trays, the rooted cuttings were used for recording the root and shoot parameters. The experiments were subjected to statistical scrutiny following the method of Gomez and Gomez (1984).

\section{Results and Discussion}

In the present study nineteen endophytic bacteria were isolated from eight crop plants viz. rice (Oryza sativa), ragi (Eleusine corocana), cowpea (Vigna ungiculata), soybean (Glycine max), groundnut (Arachis hypogea), sunflower (Helianthus annus), chilli (Capsicum annuum) and tomato (Lycopersicon esculentum).

Of the nineteen isolates, seven isolates belonged to the genus Bacillus and the Gram negative bacteria belonged to the genera Citrobacter, Klebsiella, Acinetobacter, Pseudomonas and Vibrio which were predominantly present in vegetables. The production of plant growth regulators Gibberellic acid (GA) and Indole acetic acid (IAA) by the endophytic bacterial isolates was estimated by spectrophotometry and the results are given in Table 1. In the present study, all the endophytic isolates were found to produce both the plant growth regulators in the media. The GA concentration in $25 \mathrm{ml}$ of the culture filtrate varied from $9.91 \mu \mathrm{g}$ in the soybean isolate GME16 to $1.1 \mu \mathrm{g}$ in sunflower isolate HAE7. The highest IAA production was by the tomato isolate LEE19 $(212.30 \mu \mathrm{g}$ of IAA) while $50 \%$ of the isolates produced $\leq 10 \mu \mathrm{g}$ IAA. 
Effect of endophytic bacteria on the rooting and establishment of cuttings of Hibiscus rosasinensis

Table 1. Estimation of plant growth regulators (GA, IAA) produced by endophytic bacteria

\begin{tabular}{|c|c|c|c|c|c|}
\hline $\begin{array}{l}\text { Host } \\
\text { group }\end{array}$ & Host & Isolates & Tentative identification & $\mathrm{GA}(\mu \mathrm{g})^{*}$ & IAA $(\mu \mathrm{g})^{*}$ \\
\hline \multirow{5}{*}{ Cereals } & \multirow{2}{*}{ Rice } & OSE1 & Bacillus pasteurii & $5.22^{f}$ & $205.40^{\mathrm{b}}$ \\
\hline & & OSE2 & Citrobacter sp. & $7.18^{\mathrm{d}}$ & $7.53^{\mathrm{hi}}$ \\
\hline & \multirow{3}{*}{ Ragi } & ECE4 & Bacillus sp. & $5.27^{\mathrm{f}}$ & $147.08^{\mathrm{d}}$ \\
\hline & & ECE5 & Bacillus pasteurii & $4.53^{\mathrm{g}}$ & $62.97^{\mathrm{e}}$ \\
\hline & & ECE6 & Klebsiella sp. & $5.79^{\mathrm{e}}$ & $181.83^{\mathrm{c}}$ \\
\hline \multirow{3}{*}{ Oilseeds } & Groundnut & AHE3 & Bacillus sp. & $5.11^{\mathrm{f}}$ & $44.79^{\mathrm{f}}$ \\
\hline & \multirow{2}{*}{ Sunflower } & HAE7 & Acinetobacter sp. & $1.10^{\mathrm{k}}$ & $203.42^{b}$ \\
\hline & & HAE8 & Klebsiella sp. & $8.74^{\mathrm{c}}$ & $4.74^{\mathrm{hi}}$ \\
\hline \multirow{4}{*}{ Pulses } & \multirow{2}{*}{ Cowpea } & VUE13 & Bacillus megaterium & $9.14^{b}$ & $7.23^{\text {hi }}$ \\
\hline & & VUE14 & Bacillus sp. & $2.14^{\mathrm{i}}$ & $3.23^{\mathrm{i}}$ \\
\hline & \multirow{2}{*}{ Soybean } & GME15 & Bacillus sp. & $2.53^{\mathrm{h}}$ & $3.59^{1}$ \\
\hline & & GME16 & Pseudomonas sp. & $9.91^{\mathrm{a}}$ & $3.48^{i}$ \\
\hline \multirow{7}{*}{ Vegetables } & \multirow{4}{*}{ Chilli } & CAE9 & Acinetobacter sp. & $4.82^{\mathrm{g}}$ & $4.01^{\mathrm{i}}$ \\
\hline & & CAE10 & Citrobacter sp. & $4.58^{\mathrm{g}}$ & $10.77^{\mathrm{h}}$ \\
\hline & & CAE11 & Pseudomonas sp. & $9.10^{b}$ & $4.95^{\mathrm{hi}}$ \\
\hline & & CAE12 & Acinetobacter sp. & $5.59^{\mathrm{e}}$ & $18.48^{\mathrm{g}}$ \\
\hline & \multirow{3}{*}{ Tomato } & LEE17 & Vibrio sp. & $0.62^{1}$ & $6.07^{\mathrm{h}}$ \\
\hline & & LEE18 & Pseudomonas sp. & $9.14^{b}$ & $68.90^{\mathrm{e}}$ \\
\hline & & LEE19 & Klebsiella sp. & $0.22^{\mathrm{m}}$ & $212.30^{\mathrm{a}}$ \\
\hline $\begin{array}{l}\text { Reference } \\
\text { culture }\end{array}$ & $\begin{array}{l}\text { Azotobacter } \\
\text { chroococcum }\end{array}$ & AZC20 & $\begin{array}{l}\text { Azotobacter } \\
\text { chroococcum }\end{array}$ & $1.47^{\mathrm{j}}$ & $4.51^{\mathrm{h}}$ \\
\hline \multicolumn{4}{|c|}{ SEd } & 0.13 & 3.27 \\
\hline \multicolumn{4}{|c|}{$\mathrm{CD}(0.05)$} & 0.26 & 6.63 \\
\hline
\end{tabular}

Note: Spectrophotometric estimation for GA and IAA.

*Estimated from $25 \mathrm{ml}$ culture filtrate concentrated to $2 \mathrm{ml}$.

Different letters in superscripts indicate significantly different values.

For the rooting of cuttings, four isolates viz., the ragi isolate ECE6, sunflower isolate HAE7, the tomato isolates LEE18 and LEE19 and the consortium of the four were used. They were selected as they were found to produce more IAA and GA compared to other isolates.

The effect of the endophytic bacteria on the sprouting \% at 90days, shoot parameters like shoot length, no of sprouts/ cutting and the no of leaves / cuttings are presented in Table 2 . By $90^{\text {th }}$ day the endophytic treated plants showed better sprouting $(75 \%)$ than the commercial formulation Quicroot $(62.5 \%)$ and $100 \%$ sprouting was recorded in IBA treatment. The treatment with the consortium showed $50 \%$ sprouting. Control had only $33.3 \%$ sprouting. IBA treatment recorded the highest shoot length, number of sprouts and leaves and the least was in uninoculated control. Among the endophytic isolates LEE19 was the best followed by LEE18. Consortium recorded shoot length of $26 \mathrm{~cm}$. The probable reason for increase in length of shoot may be the better utilization of carbohydrates, nitrogen and other nutrients which has been aided by growth regulators. The possible reason for the increase in the number of leaves and sprouts may be due to the activation of shoot growth which probably increased the number of nodes that lead to development of more number of leaves.

Table 2. Effect of endophytic bacteria on shoot parameters of Hibiscus rosasinensis cuttings.

\begin{tabular}{|l|c|c|c|c|}
\hline Treatments & Sprouting \% & $\begin{array}{c}\text { Shoot } \\
\text { length } \\
(\mathrm{cm})\end{array}$ & $\begin{array}{c}\text { No of } \\
\text { sprouts/ } \\
\text { cutting }\end{array}$ & $\begin{array}{c}\text { No of } \\
\text { leaves/ } \\
\text { cutting }\end{array}$ \\
\hline T1 - Uninoculated control & $33.30(35.23)^{\mathrm{e}}$ & $22.0^{\mathrm{g}}$ & $4.5^{\mathrm{f}}$ & $35.0^{\mathrm{g}}$ \\
\hline $\begin{array}{l}\text { T2 - Commercial formulation (Quicroot } \\
\text { dip for 30s) }\end{array}$ & $62.50(52.18)^{\mathrm{c}}$ & $37.8^{\mathrm{c}}$ & $6.0^{\mathrm{d}}$ & $48.0^{\mathrm{f}}$ \\
\hline $\begin{array}{l}\text { T3 - Chemical control (IBA 2500ppm } \\
\text { for 30s) }\end{array}$ & $100.00(89.96)^{\mathrm{a}}$ & $43.5^{\mathrm{a}}$ & $13.0^{\mathrm{a}}$ & $168.0^{\mathrm{a}}$ \\
\hline T4- Ragi isolate ECE6 & $75.00(59.97)^{\mathrm{b}}$ & $21.0^{\mathrm{e}}$ & $9.0^{\mathrm{c}}$ & $128.0^{\mathrm{c}}$ \\
\hline T5 - Sunflower isolate HAE7 & $50.00(44.98)^{\mathrm{d}}$ & $39.0^{\mathrm{b}}$ & $9.0^{\mathrm{c}}$ & $94.0^{\mathrm{d}}$ \\
\hline T6- Tomato isolate LEE18 & $75.00(59.97)^{\mathrm{b}}$ & $38.3^{\mathrm{bc}}$ & $12.0^{\mathrm{b}}$ & $149.0^{\mathrm{b}}$ \\
\hline T7 - Tomato isolate LEE19 & $75.00(59.97)^{\mathrm{b}}$ & $37.3^{\mathrm{c}}$ & $13.0^{\mathrm{a}}$ & $152.0^{\mathrm{b}}$ \\
\hline T8- Consortium of ECE6, HAE7, & $50.00(44.98)^{\mathrm{d}}$ & $26.0^{\mathrm{f}}$ & $5.0^{\mathrm{e}}$ & $58.0^{\mathrm{e}}$ \\
\hline
\end{tabular}


Effect of endophytic bacteria on the rooting and establishment of cuttings of Hibiscus rosasinensis

\begin{tabular}{|l|c|c|c|c|}
\hline LEE18 and LEE19 & & & & \\
\hline SEd & 0.8274 & 0.49 & 0.26 & 2.26 \\
\hline $\mathrm{CD}(0.05)$ & 1.7748 & 1.06 & 0.55 & 4.84 \\
\hline
\end{tabular}

Note: Arcsine transformed values are indicated in parantheses.

Different letters in superscripts indicate significantly different values.

Sprouting per cent $=\underline{\text { No of cuttings with fresh sprouts }} \times 100$

No of cuttings planted

The results of the effect of the bacterial endophytes on rooting parameters like rooting percentage, root length, fresh weight and dry weight of roots recorded after 90 days of planting are presented in Table 3. $100 \%$ rooting was observed in IBA treatment as well as LEE19 inoculation. The commercial formulation Quicroot and the other test endophytes showed $80 \%$ rooting. The least rooting of $60 \%$ was recorded in uninoculated control and combination of endophytic isolates. The basis for this may be the enhancement of hydrolysis of nutrient reserves by auxin treatments. Increased number of roots due to auxin application is a common feature in many herbaceous perennial crops $[7,8]$. The length and dry weight of roots showed significant difference between treatments. It was highest in IBA treatment and least in uninoculated control. Among the endophytic treatments the best was found to be LEE19.

Table 3. Effect of endophytic bacteria on root parameters of Hibiscus rosasinensis cuttings.

\begin{tabular}{|l|c|c|c|}
\hline Treatments & Rooting (\%) & $\begin{array}{c}\text { Root length } \\
(\mathrm{cm})\end{array}$ & $\begin{array}{c}\text { Root Dry } \\
\text { weight }(\mathrm{g})\end{array}$ \\
\hline T1 - Uninoculated control & $60(50.75)^{\mathrm{c}}$ & $9.06^{\mathrm{g}}$ & $0.019^{\mathrm{d}}$ \\
\hline $\begin{array}{l}\text { T2 - Commercial formulation (Quicroot dip for } \\
\text { 30s) }\end{array}$ & $80(63.41)^{\mathrm{b}}$ & $37.75^{\mathrm{b}}$ & $0.091^{\mathrm{ab}}$ \\
\hline T3 - Chemical control (IBA 2500ppm for 30s) & $100(89.96)^{\mathrm{a}}$ & $48.50^{\mathrm{a}}$ & $0.105^{\mathrm{a}}$ \\
\hline T4- Ragi isolate ECE6 & $80(63.41)^{\mathrm{b}}$ & $30.2^{\mathrm{d}}$ & $0.068^{\mathrm{bc}}$ \\
\hline T5 - Sunflower isolate HAE7 & $80(63.41)^{\mathrm{b}}$ & $26.50^{\mathrm{e}}$ & $0.057^{\mathrm{c}}$ \\
\hline T6- Tomato isolate LEE18 & $80(63.41)^{\mathrm{b}}$ & $31.50^{\mathrm{d}}$ & $0.044^{\mathrm{c}}$ \\
\hline T7 - Tomato isolate LEE19 & $100(89.96)^{\mathrm{a}}$ & $35.40^{\mathrm{c}}$ & $0.084^{\mathrm{b}}$ \\
\hline T8 - Consortium of ECE6, HAE7, LEE18 and & $60(50.75)^{\mathrm{c}}$ & $21.00^{\mathrm{f}}$ & $0.035^{\mathrm{c}}$ \\
LEE19 & & & \\
\hline SEd & 3.46 & 0.47 & 0.01 \\
\hline CD $(0.05)$ & 7.42 & 1.03 & 0.03 \\
\hline
\end{tabular}

Note: Arcsine transformed values are indicated in parantheses.

Different letters in superscripts indicate significantly different values.

Rooting per cent $=$ No of cuttings with roots $\times 100$

No of cuttings planted

Similar results were obtained in poplar cuttings by Taghavi et al. [9]. They reported that the poplar cuttings inoculated with endophytic Enterobacter sp. strain 638 and Bacillus cepacia BU72 showed statistically better growth than the control plants and showed increased root biomass. Aravind et al. [10] also reported superior sprouting behavior, number of leaves, root biomass and total biomass of the plantlets of black pepper stem cuttings when inoculated with endophytic Pseudomonas aeruginosa and Bacillus megaterium treatments than the untreated stem cuttings.

\section{Conclusions}

The treatment of cuttings with the tomato isolate LEE19 (Klebsiella sp.) for 12 hours, showed $75 \%$ sprouting of cuttings and the highest shoot and root parameters compared to uninoculated cuttings. The tomato isolate LEE18 (Pseudomonas sp.) and the ragi isolate ECE6 (Klebsiella sp.) were the next best isolates with 80 $\%$ rooting. The root length and root biomass in these treatments were comparable to that of the application of commercial formulation Quicroot.

The best treatment for all the parameters was the tomato isolate, LEE19 (Klebsiella sp.). This isolate was found to produce $212 \mu \mathrm{g}$ of auxin per $25 \mathrm{ml}$ of culture filtrate. Hence each cutting was estimated to imbibe $17.5 \mu \mathrm{g}$ for the plant hormone which may be responsible for the enhanced rooting in these cuttings. The reason may be attributed to enhanced tissue sensitivity and increased rooting via increased internal free auxins resulting in increased number of roots. Another possible reason may be due to translocation of carbohydrates from the leaves which plays important role in root development [11]. So the pre-plant stem treatment of cuttings can be recommended as a strategy for substituting or supplementing the use of chemical plant growth hormones in vegetative propagation of cuttings. 


\section{References}

[1] B. Schulz and C. Boyle, What are endophytes? In: B.J.E. Schulz, ,C. J. C. Boyle and T. N. Seiber, (Eds.) Microbial Root Endophytes (Berlin: Springer-Verlag, 2006) 1-13.

[2] K. R. Aneja, Experiments in Microbiology, Plant Pathology and Biotechnology (New Delhi: New Age International Publishers, 2006) 245-275.

[3] T. Tien, M. Gaskin, and D.Hubbel, Plant growth substances produced by Azospirillum brasilense and their effect on the growth of pearl millet (Pennisetum americanum L.), Appl Environ. Microbiol., 37, 1979, 1016-1024.

[4] L.G. Paleg, Physiological effects of gibberellins. Ann. Rev. Plant Physiol., 16, 1965, 291-322.

[5] A.S. Gordon and R.P. Weber, Colorimetric estimation of indole acetic acid. Plant Physiol., 26, 1951, $192-195$.

[6] K. A. Gomez and A. A. Gomez, Statistical procedures for Agricultural Research. (New York: Wiley-Interscience Publication., John Wiley and Sons, 1984) 680.

[7] B. E. Haissing and F. T. Davis, Carbohydrate accumulation and participation in Pinus banksiana seedlings and seedling cuttings. Physiologia plantarum, 61, 1984, 13-19.

[8] H. T. Hartmann, D. E. Kester, F. T. Davies R. L. and Geneve, Plant Propagation, Principles and Practices (New Delhi : Prentice Hall of India Pvt. Ltd, 2002.)

[9] S. Taghavi, C. Garafola, and S. Monchy, Genome survey and characterization of endophytic bacteria exhibiting a beneficial effect on growth and development of poplar. Appl. Environ.Microbiol., 75, 2009, 748-757.

[10] R. Aravind, A. Kumar and S.J. Eapen, Pre-plant bacterisation: a strategy for delivery of beneficial endophytic bacteria and production of disease-free plantlets of black pepper (Piper nigrum L.). Arch. Phytopathol. Plant Protection, 48, 2012 , 1-12.

[11] M. D. Carvalho, L. Zaidan and C. M. De, Propagation of Stevia rebaudiana from stem cuttings. Persquisa-agropecuaria-brasileira, 30, 1995, 201-206. 